\title{
AUTOBIOGRAPHICAL STRATEGY AND ATTITUDE OF HALINA BIRENBAUM AS A FORM OF PASSING ON A WITNESS OF THE HOLOCAUST
}

\author{
by Katarzyna Olszewska
}

Halina Birenbaum, born in Poland and living since 1947 in Israel, is a poet and writer. She spent her childhood in the Warsaw ghetto, from where in 1943 she was transported to Majdanek and next to Auschwitz-Birkenau. In 1945, she survived the death march, which led her to the camps of Ravensbrück and Neustadt-Glewe, where she stayed until liberation. The post-war period spent in Warsaw 'kibbutzim' Ichud and Hashomer Hatzair made her seek refuge in the 'land of the forefathers.' She emigrated from Poland during the 'Bricha' action and went through months of wandering, leading her, inter alia, to Bratislava, Prague, the camp in Airing, Bad Reichenhall, Eschweige and France. She began her life in the new motherland in kibbutzim to finally settle down with her husband and children in the town of Herzliya, where she still lives today.

Halina Birenbaum is a member of the Polish Writers' Association in Israel. She translates Polish literature into Hebrew and takes up a number of initiatives aimed at-as she says-"more reconciliation than repairing the Polish-Jewish relations" (Kuryłek, 2006, p. 277) as well as the relations between the Jews and the Germans. For her social activity, the writer was awarded the medal 'Pax 1939-1945' (1996), the 'Auschwitz Cross' (1997), the 'Officer's Cross of the Order of the Rebirth of Poland' (1999), and the Polish Council of Christians and Jews granted her the title of the 'Reconciliation Person of 2001.' The books written by Halina Birenbaum in Polish have had numerous translations, also into Hebrew and German. Her prose achievements include: Nadzieja umiera ostatnia (Hope is the last 
to die) ${ }^{1}$ (1967), Powrót do ziemi praojców (Return to ancestors' land) (1991), Każdy odzyskany dzień: Wspomnienia (Every recovered day: Memories) (1998) and Wotanie o pamiećc (Scream for remembrance) (1999), as well as a collection of texts enriched with photographs taken by Adam Bujak, Życie każdemu drogie (Life treasured by everyone) (2005). ${ }^{2}$ The poetic achievements of Halina Birenbaum have been collected in volumes of poetry: Wiersze Haliny Birenbaum (Poems of Halina Birenbaum) (1987), Nawet gdy się śmieje (Even when I laugh) (1990), Nie o kwiatach (Not about flowers) (1993), Jak można w stowach (How in words) (1995), Echa bliskie i dalekie: Spotkania z młodzieża (Echoes, close and far: Meetings with young people) (2004), Moje życie rozpoczęto się od końca (My life began with the end) (2010). ${ }^{3}$

The genesis and the prevailing theme of all her works is the war, and especially the Holocaust, whose unique nature and moral obligation associated with it induced the writer to embed her creative efforts in the autobiographical material, recalled from memory or experienced in parallel with the elaboration of the literary pieces. As a survivor of the Holocaust, at the urging of her husband (Maliszewski, 1988, p. 11), and also under the influence of a discourse aroused by Eichmann's trial in Jerusalem (Kuryłek, 2006, p. 258), in 1963 she decided to take a stand on the Shoah: "[...] something very important was missing for me-the atmosphere of unceasing horror of everyday life spent in the midst of all the atrocities of war, when every hour was an eternity, or an hour preceding this eternity" (Birenbaum, 1991, p. 231). The writer has attempted to oppose the anonymity of the crime and its impersonal dimension, building in her texts personal monuments commemorating those who were exterminated, as well as constructing a story not only by events, but also sensations and emotions experienced by people condemned to death.

Scholars researching the literature devoted to the Holocaust generally emphasize its cleansing and therapeutic nature, consisting in shifting the burden of various traumatic experiences from the author to the reader, which allows for commencing a new life. This psychological mechanism also applies to the writing practiced by Halina Birenbaum (1993, p. 32, 37) (uspokaja, kiedy pisze) (writing calms me down), who always stresses, though, that the Holocaust is an inherent and indelible part of the personality of the witness. Separating oneself from the past with the wall of oblivion leads

1 In the main text, the original titles are followed by their counterparts in English. Halina Birenbaum has used a specific wordplay involving the peculiar use of small and capital letters and we have done our best to reflect the Author's intentions in the translations of the titles.

2 There are also some poems in this book.

3 The volume comprises the whole of poetic achievements of Halina Birenbaum. 
to mental disability (Birenbaum, 1999, p. 148), and that is why the poet 'screams for remembrance' of the Shoah. The autobiographical attitude of her creative output shows an attempt undertaken by the author to process the trauma, understand herself and melt her Polish-Jewish-Israeli identity into one wholeness. The specific addressee of the poet's works turns out to be the subject of the utterances seeking the truth about itself. However, the testimony of the Holocaust first and foremost must reach the widest possible group of readers and fit in the space of collective memory. The task which the author has set for her works faces resistance from the recipient, defending himself/herself against difficult and sometimes controversial as well as overwhelming knowledge (temat-niepożadany) (topic-unwanted) (Birenbaum, 1995, p. 9). Conscious of the response on the part of the readers (nie zawsze tam dobrze) (not always good there) (Birenbaum, 2010, p. 311), the poet firmly and consistently strives to establish communication, requests even somewhat insistently to be heard, which undoubtedly is facilitated by autobiographism chosen as the key literary strategy.

Halina Birenbaum's artistic path already at the very beginning was marked by a number of hindrances. The circumstances of her book debut did not provide a conducive atmosphere for the topics tackled by the author. At that time, in Israel, manifesting the Polish past was considered unnecessary and shameful (Rybak, 1996, p. 28). Jewish society felt aversion to Poles, due to a sense of neighborly betrayal and wrongs suffered by its members (ibid., p. 28). The Israeli had enough troubles of their own and unpleasant experiences which they did not want to aggravate through other people's misfortunes. Everyone lacked the strength to confront the painful past (Meloch, 1999, p. 67). Over the years, the Holocaust was a taboo subject among the Jews, also because their young country, fighting for independence, needed positive reinforcement constituting the nation and the army, and that was felt to be damaged by accounts of-as was then thought-"passive and helpless victims" (Tuszyńska, 1993, p. 31). Despite the difficulties outlined above, Nadzieja umiera ostatnia (Hope is the last to die) was a publishing success and reached a significantly broad audience. The publication of subsequent books of the author has confirmed the effectiveness of the autobiographical strategy and attitude, the discussion of which requires some theoretical introduction.

The autobiographical attitude is a subject of considerations of Małgorzata Czermińska (1982, pp. 226-227), who indicates the category of similarity or full identification of the author with the main character (the narrator) as a prerequisite for the existence of that attitude. According to the researcher, the recognition of the identity hidden in the text is primarily based on the beyond-the-text knowledge of the author, sometimes camouflaging 
the authenticity of the narrative, and playing a game with the reader. Małgorzata Czermińska distinguishes two extreme variations of this phenomenon: the extraverted one ("where we see the world through the prism of the experiences of ' $\mathrm{I}^{\prime \prime}$ ") and the introverted one ("where the world is only the source of impulses for the experiences taking place inside ' $\mathrm{I}^{\prime \prime}$ ") (ibid., p. 229), supplementing them in the later work with the attitude of a challenge, where the recipient is placed in the foreground (ibid., pp. 12-16).

The theory coined by Małgorzata Czermińska was modified by Jerzy Smulski (1988, pp. 83-101), who linked the autobiographical approach to the signals given in the structure of a literary text or in the inter-text relationships covering the entire artistic output of an artist (e.g. repetition of scenes and themes in several works created by the same person). On the other hand, a direct relationship of the author's biography and the fictional events contained in his/her works is defined by Smulski as an autobiographical strategy, implemented by, among other means, giving interviews and writing memoirs.

The artistic activity of Halina Birenbaum follows the above-described model of autobiographism. The key interpretation context of her books is the biography concentrated on the subject of the Holocaust experience, emigration to the Holy Land and life in Israel. The literary pieces written by Halina Birenbaum, which are not easy to receive, need a proper setting, and so she consciously assumes an autobiographical attitude together with its strategy of communication with the reader: "They do not have to listen to me. [...] I'm interested in their listening to me" (Kuryłek, 2006, p. 274). The author willingly participates in interviews, talking about what she lived through in Poland, confirming in that way the authenticity of the events portrayed in her literary texts (Magdziak-Miszewska, 2001, pp. 6470; Wałęcki, 2001, p. 4). She takes part in meetings with the readers, which often turn into evenings filled with memories and stories that are almost ready passages of prose. According to Katarzyna Meloch (1999, pp. 68-69), the writing of Halina Birenbaum, similarly to folk epic poetry, is born from stories told aloud. The writer herself values spoken sources more than the written ones, because of the greater effect caused by the contact with the living human being and engrafting personal experience in the memory of the listeners (Kuryłek, 2006, p. 259). The writer engages herself in meetings with young people from all around the world ${ }^{4}$ to build a bridge of understanding

4 Halina Birenbaum took part, inter alia, in: international meetings with 'Evangelical Young Working People' and 'A Sign of Penance' organized by "Deutscher Evangelischer Kirchentag," meetings at the Youth Meeting House and the Center for Dialogue, Education and Prayer in Oświęcim, the Polish-German Symposium in Ustronie on AntiSemitism and Hatred towards Foreigners Yesterday and Today, readings in many places in Israel (since 1966), travels with the Jewish youth to Poland (since 1996). 
between people. In addition to this, she participates in creating radio programs ${ }^{5}$ and movies, ${ }^{6}$ and she publishes memoirs. She also replied to the survey organized by Więz (Tie) ${ }^{7}$ regarding the message of the Pope, John Paul II. Apart from that, the poet regularly hosts, in her own house, pupils and students from different religious backgrounds (ibid.).

The autobiographical strategy is also present at the level of the relationship between poetry and paraliterary texts (Smulski, 1988, pp. 83-85), which include: a diary with the Author's introduction and epilogue depicting the years of World War II, Nadzieja umiera ostatnia (Hope is the last to die); a diary from the emigration period, Powrót do ziemi praojców (Return to ancestors' land); a diary enriched with memories and metatextual reflections covering the period 1966-1997, Każdy odzyskany dzien (Every recovered day) and memories devoted to the lives of twenty Survivors of the Holocaust, Wotanie o pamieć (Scream for remembrance). The comparative analysis of the strictly literary and paraliterary texts of Halina Birenbaum reveals the relationship between her poems and her biography through identifying the sources of literary motifs and archetypes of the characters of brother Chilek or son Yakov. The most important symbols-keys include the theme of bereavement and the night spent in a gas chamber. The painful feeling of missing the mother is mentioned by the author in Powrót do ziemi praojców: "In general, I clung to people older than myself, as if I was looking for a replacement for my mother and father whom I lost so early" (Birenbaum, 1991, p. 202). The theme of bereavement also appears in Wotanie o pamięć: "Many years ago I met by chance an old, lonely woman. [...] She had a similar Auschwitz tattoo on her forearm. I could not break in any way from the effect of this look. To this day" (Birenbaum, 1999, pp. 11-12). In Każdy odzyskany dzien, the writer confesses, "I know that burning pain when the mother is taken away from the child. [...] I know this biting helplessness at the sight of the torment and death of the loved ones" (Birenbaum, 1988, p. 46). The diary Nadzieja umiera ostatnia includes a description of the moment of her being separated from the mother in Majdanek: "I felt as if I suddenly had my hands and feet chopped off. [...] She had just been taken away. Why? I could not reconcile with the idea that she was gone, that I would never see her again! [...] I was going in circles like a machine and repeating mechanically, 'My mum is gone'" (ibid., p. 96). The figure of the mother appears quite often in the poems of Halina Birenbaum: "I am always with you, Mom / Your figure

5 I was 10 when the war broke out-a broadcast of the Polish Radio (1989).

6 Because of the war-a biographical film, in which Halina Birenbaum talks about the experiences of the years 1939-1945, as well as about her life in Israel.

7 Catholic monthly magazine published in Poland, with a short break, since 1958. 
is impressed in me / and lasts / they tore You away before the deceptive bath / in Majdanek" (Nie o kwiatach) (Not about flowers) (Birenbaum, 1993, p. 3). The scene of being accidentally saved from the gas chamber (Birenbaum (1988, p. 256)-the author mentions it, inter alia, in the book Nadzieja umiera ostatnia)-is also depicted in the poems, chciatam (I wanted) (Birenbaum, 1995, p. 11): "I lived through all here / all my life / my death", Frum (ibid., p. 15): "I was dragged to Birkenau / from the ghetto of Warsaw / from the Majdanek gas chamber", Nie warto śnić (Not worth dreaming) (Birenbaum, 2001, p. 51), and Biada temu kto sie zbliży (Woe to whoever comes near) (Birenbaum, 1995, p. 22). In the writings of the Shoah Survivor, we can indicate a lot of similar themes and topics, returning also in her poetry, for example, a train leaving the station in Warsaw in 1942, images of the ghetto along with the names of the streets: Muranowska and Nowolipie or number 27 of the camp block, where she stayed in Auschwitz-Birkenau.

The author includes in her notes reflections on her own creative work and the way of telling the story of the Holocaust, whose dimension is hard to be expressed in the "language of the living people" (ona tam czekała) (she was there waiting) (Birenbaum, 2001, pp. 42-44). The writer's diaries contain information approximating problems with publishers ${ }^{8}$ and those regarding the perception of the literary pieces, carefully tracked and reported by the poet. The concerns related to the reaction of the readers are also present in the poem temat-niepożadany (topic-unwanted) (Birenbaum, 1995, p. 9): "Is my book story poem / again?!... about the Holocaust? /-I defend explain justify [...] / the topic unwanted difficult." Furthermore, in her collections of poems, there can be found pieces on specific events, such as the one with the date of December 10, 1982, titled do nastepnego spotkania (to the next meeting) (Birenbaum, 2001, p. 56), describing the discussions with young people in Massuah. The diary, under the same date, presents an account of that meeting. All these efforts shown above make up a consistently implemented autobiographical strategy, acting for the recipient as a guarantee of the truth contained in a literary text.

Also the autobiographical attitude, along the autobiographical strategy, serves making the message from the author authentic. This is most significantly emphasized by the identity of the author and narrator in the text. In the case of poems by Halina Birenbaum, it is difficult to verify the compatibility of the name or surname, but their role is fulfilled by the camp tattoo, referred to by the lyrical subject as the "identity card from Auschwitz" (numer na moim ramieniu) (the number on my arm) (ibid., p 52). Similarly, in the

8 The author mentions in Every recovered day, on August 8, 1966, the impending date of publication of her first book which was released in 1967. 
poem tam mój duch (there my spirit), the lyrical subject says, "no matter where I live / when how where I will die / wherever in the world / they will bury my body / labeled with the number 48693 here / tattooed" (Birenbaum, 1995, p. 16). This number also appears on the cover of the volume and is consistent with the number assigned to the artist in Auschwitz-Birkenau. ${ }^{9}$ By indicating the camp number, the author makes with the reader "the autobiographical pact" (Lejeune, 1989, pp. 3-30), which allows for receiving her poems as an autobiography. Despite the fact that the construction of the volumes shows no cyclical character or chronology consisting of childhood and youth, many poems strive to offer an overview of the author's life and conduct. The subject of the utterances ponders on her attitude to other people and is looking in herself for the signs of the desire for revenge and hate (czy nienawidzę Niemców) (do I hate the Germans) (ibid.). The comparison of the girl from the time of the Holocaust and the mature woman provides evidence indicating that the poet's works are autobiographical in nature.

What can be noticed while looking at all poetic achievements of Halina Birenbaum is the persevering character of several motifs. The recurrent subjects are indicated by the titles of the poems, such as 19 kwietnia przed czterdziestu laty, po czterdziestu latach, dopóki Ich wspominamy Oni żyja, jestem ich nagrobkiem, turystka grobów, szukam życia u umartych, nie daję umrzeć (April 19 forty years ago, after forty years, They live as long as They are remembered, I am their tomb, tourist of the graves, I am looking for life in the dead, I do not let die), outlining the regions of the author's poetic imagination. The poems may be divided into several interrelated thematic circles, including the childhood marked with fear and starvation in the Warsaw Ghetto (W naszym pokoju $w$ getcie, pociagi po prostu, Miałam przyjaciótke w Warszawskim Getcie, Tego lata, To byt tylko poczatek, zapach chleba z getta) (In our room in the ghetto, just trains, I had a friend in the Warsaw Ghetto, That summer, It was just the beginning, the smell of bread in the ghetto), the mother's death in Majdanek (Gefilte Fish, jestem Zawsze z Toba, ona tam czekata, zapach chleba w getcie, jestem, jej już nie było, Czy mnie widzisz, Mamo?) (Gefilte Fish, I am Always with You, she was there waiting, the smell of bread in the ghetto, I am, she was already gone, Can you see me, Mom?), the Holocaust (extermination) camps symbolized by the chimneys and crematoria (chciałam, Fruma, tam mój duch, Biada temu kto się zbliży, turystka grobów, byłam tylko okruchem, jesień w Treblince, Długie Domki, Tutaj, Jedźcie do Treblinki, jestem, styczeń) (I wanted, Frum, my spirit there, Woe to whoever comes near, tourist of the graves, I was only a crumb, fall in Treblinka, Long Little Houses, Here, Go to Treblinka, I am, January) and the dual

9 Halina Birenbaum was registered and imprisoned at Auschwitz as Hala Grynsztejn (see Birenbaum, 2003). 
Polish-Israeli identity (Jamim Noraim, polska nostalgia, Alte Zachen, Tęsknota, Wróciłam do domu, moja polska zima, moje dwie ojczyzny) (Yamim Noraim, Polish nostalgia, Alte Zacheni, Longing, I came home, my Polish winter, my two homelands). The recurring themes and images, rooted in the memory of the lyrical subject and the matter of the texts demonstrate continuous experiencing of the traumatic past, which finds an outlet in creative work.

Lyrical ' $\mathrm{I}$ ' appears in the majority of these poems in the first person. Establishing the memories as the subject of the utterances, the lyrical subject adopts the attitude of the witness, but sometimes also focuses its attention on its own experiences, adopting then the attitude of testimony (Czermińska, 2000, pp. 12-16) and confidences. The atmosphere of sincerity and privacy of expression corresponds to an invitation offered to the reader to be heard: "I' $m$ sad / it is hard to part with Warsaw / [...] makes me want to cry / [...]-what huge baggage / I carry away from here in my soul to home" ( $W$ drodze powrotnej do Izraela) (On the way back to Israel) (Birenbaum, 2010, p. 180).

The poetry of Halina Birenbaum comprises self-reflexive elements, making it easier to identify the poet with the hero of the poems. An eloquent component of an autobiographical attitude are the dates marking when the majority of the poems was created and later placed in the books of poetry. ${ }^{10}$ A characteristic example is the poem with the date of January 1, 1968, titled pierwsza godzina w nowym roku (the first hour of the new year): “It's one o'clock at night / there has already come the new year / embraced the rule over us / and I have not managed / to summarize what I experienced / in the year which left one hour ago / or to think about / what can be expected in this new one" (Birenbaum, 1995, p. 40). In addition, lyrical I weaves a reflection on the creation of poetry. Birenbaum's texts are soaked with the awareness of the recorded words becoming a document (Michalski, 1992, p. 276): "no one can / break my pen / snatch my mightiest weapon away / my ability to remember / -record / and they are life / or even a lot more" (franges non flectes) (Birenbaum, 1995, p. 7). The revelation of the professional role of the narrator makes the reader treat the words of a literary text as utterances of a genuine person.

The identification of the narrator with the author is evidenced in the so-called mental unity (Smulski, 1988, p. 100). The life experiences of Halina Birenbaum (1995, p. 37) are reflected in the feeling of the fragility and transience of human life emerging in her poetry: "We are in this world like flowers / Soft or less sensitive / lasting more or less-but all / one-off and temporary" (Jesteśmy jak kwiaty) (We are like flowers), as well as in mourning "Other flowers are planted-but the smell and the image / of Those that

10 Under some poems of Halina Birenbaum, in addition to the date, there is recorded the place where the poem was created, for example Herzliya, or annotations, such as "after returning from Poland." 
are gone, yet still present in the memory-do not come back" (Jesteśmy jak kwiaty) (We are like flowers), and in the fear of the Holocaust happening again piercing through the verses. Lyrical I often indicates domestication of death, accompanying her since an early age (czego się bać, Moje życie rozpoczęło się od końca) (what to fear, My life began with the end). The knowledge brought to the lyrical subject of the poems through the Holocaust facilitates a deeper look at the war and the contemporary conflict between the Israeli and the Palestinians, "to die by suicidal death in the name of hatred / sanctification of the self / alleged glory family wealth / [...] once again prove what blind faith is / and what hatred can do / and I remember longing for life / in the midst of infamous mass death" ( $w$ raju fanatyzmu) (in the paradise of fanaticism) (Birenbaum, 2010, p. 224). The Arab-Israeli war evokes traumatic memories, ideas and thoughts about the Shoah regardless of the will of the Shoah witness. A similar reaction is caused by apparently inconspicuous stimuli, such as the Christmas supper ( $w$ ciszy wielkich świat) (in the silence of the great feast) (ibid., p 222). The person speaking in the poems reveals a sense of alienation from the society that does not share her tragic past ("Pianista") ("The Pianist") (ibid., p 25). She appreciates the value of each day lived, but she cannot enjoy it like other people. Relief sometimes comes along with loneliness, far from the uncomprehending glances. Lyrical ' $\mathrm{I}$ ' is constantly struggling with her own memory, from which she escapes, to come back to it after a while. The suspension of life between times is reflected in the sense of her own identity: "I am / the inability of being divided / between the two countries / that are mine" (moje dwie ojczyzny) (my two homelands) (Birenbaum, 2001, p. 78).

The creativity and publishing success of Halina Birenbaum show that autobiographical attitude can be an extremely effective, but also a painful and exhausting artistic practice. Sentences supported by life matter sometimes convince more strongly than sophisticated poetry. The authenticity of simple words is the strength of these literary pieces, because today, in the stories of the Holocaust, what is the most frightening is the awareness that they occurred not so long ago-indeed-and that they can happen again.

\section{References}

Birenbaum, H. (2010). Moje życie zaczęło się od końca. Oświęcim: Państwowe Muzeum Auschwitz-Birkenau.

Birenbaum, H. (2003). Życie jako nadzieja: Moje lata-wieki w Shoah. Zwoje, 3, http:/ / www.zwoje-scrolls.com/zwoje36/text21p.htm [last accessed: April 13, 2012]. 
Birenbaum, H. (2001). Echa dalekie i bliskie: Spotkania z młodzieżą. Kraków: Państwowe Muzeum Auschwitz-Birkenau/Fundacja Kultury Chrześcijańskiej ZNAK.

Birenbaum, H. (1999). Wotanie o pamięć. Oświęcim: Państwowe Muzeum AuschwitzBirkenau.

Birenbaum, H. (1998). Każdy odzyskany dzień: Wspomnienia. Kraków: Znak.

Birenbaum, H. (1995). Jak można w słowach: Wybór wierszy. Kraków - Oświęcim: Centrum Dialogu.

Birenbaum, H. (1993). Nie o kwiatach. Kraków: BUS.

Birenbaum, H. (1991). Powrót do ziemi praojców. Warszawa: Czytelnik.

Birenbaum, H. (1988). Nadzieja umiera ostatnia. Warszawa: Czytelnik.

Czermińska, M. (2000). Autobiograficzny trójkat: Świadectwo, wyznanie i wyzwanie. Kraków: Towarzystwo Autorów i Wydawców Prac Naukowych Universitas.

Czermińska, M. (1982). Postawa autobiograficzna. In J. Błoński, S. Jaworski, \& J. Sławiński (Eds.), Studia o narracji (pp. 223-235). Wrocław: Zakład Narodowy im. Ossolińskich-Wydawnictwo Polskiej Akademii Nauk.

Kuryłek, A. (2006). "Tylko opowiedzieć swoją historię": O Halinie Birenbaum. In. M. Dą̧browski, A. Molisak (Eds.), Pisarze polsko-żydowscy XX wieku: Przybliżenia (pp. 256-278). Warszawa: Dom Wydawniczy Elipsa.

Lejeune, P. (1989). The Autobiographical Pact. In P. Lejeune, On Autobiography (pp. 3-30). Series: Theory and History of Literature Series, Vol. 52. (P.J. Eakin, Ed.; K. Leary, Trans.). Minneapolis: University of Minnesota Press.

Magdziak-Miszewska, A. (2001). "Dla mnie nie ma tematów tabu." Więź, 4, 64-70.

Maliszewski, M. (1988). Nadzieja umiera ostatnia [Rev.]. Kultura, 17, 11.

Meloch, K. (1999). Cudem zawieruszona cząsteczka. Więź, 7, 66-71.

Michalski, W. (1992). Powroty do spalonych gniazd. Akcent, 2-3, 274-276.

Rybak, J. (1996). Powroty do innego kraju. Rzeczpospolita, 200, 28.

Smulski, J. (1988). Autobiografizm jako postawa i jako strategia artystyczna: Na materiale współczesnej prozy polskiej. Pamiętnik Literacki, 4, 83-101.

Tuszyńska, A. (1993). Kilka portretów z Polską w tle: Reportaże izraelskie. Gdańsk: Marabut.

Wałęcki, P. (2001). "Polacy zawsze mi pomagali." Gazeta Natęczowska, 4-5, 4. 